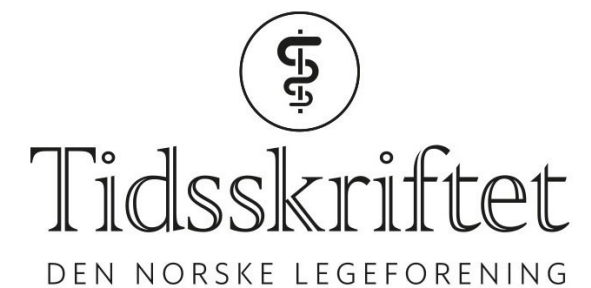

DEN NORSKE LEGEFORENING

\title{
Språkopplæring av leger med utdanning utenfor EU/EØS
}

KOMMENTAR

\section{BERGLJOT HOLM ̊̊RTAD}

E-post:linnbem@online.no Bergljot Holm Årstad er pensjonert overlege i gynekologi og obstetrikk Ingen oppgitte interessekonflikter.

Tone Greve Gedde, tidligere lektor ved Institutt for lingvistiske og nordiske studier ved Universitetet i Oslo, skriver om for lave språkkrav til leger fra utlandet (1).

Fra 1982 til 2014 var det et kurs i norsk medisinsk fagspråk som i praksis ble bare for leger. Senere forsvant språkkravene for leger som kom fra EU. Sykehusene skulle selv avgjøre hvilket nivå i norsk de ville kreve av legene de ansatte. Det nye språkkravet fra 1. januar 2017 gjelder bare for leger med utdanning utenfor EU/EØS, og kravet er bestått eksamen i B2 på Europarådets nivåskala for språk.

Greve Gedde er lingvist, og hun vurderer at kravet er for lavt fordi mange kandidater med bestått B2 ikke består eksamen i det obligatoriske kurset i nasjonale fag for leger. Dette kurset består av oppbygning og organisering av helsetjenesten, helse- og sosialrett, kulturforståelse, nasjonale satsningsområder og legemiddelhåndtering. Deretter følger en mer omfattende muntlig og praktisk fagprøve som koster 49 ooo kroner for hvert av tre tillatte forsøk.

Greve Gedde spør imidlertid ikke hvorfor eksamen i B2 er utilstrekkelig for leger for å bli god nok i norsk for kommunikasjon med pasienter og kollegaer. Det er flere mulige forklaringer.

For det første er språkkursene B1 og B2 som nå tilbys, felles for leger og andre flyktninger utenfra EU/EØS, og inneholder selvsagt ikke medisinske fagspråk.

For det andre er teksten i lærebøkene som blir brukt, langt mer enn en språkopplæring. Omtalen av det norske samfunnet er meget detaljert. Ivar Aasen skal leses, moderne dikt analyseres. Enkelte avsnitt er på nynorsk. I læreboken «Stein på stein» (2) er det diskriminerende og oppdragende avsnitt som at barn skal gå i barnehage. Man får inntrykk av at legene og flyktningene skal indoktrineres i norske regler og litteratur. Læreboken «Her på berget» (3) inneholder dessuten lange og kompliserte setninger ispedd fremmedord.

Et tilleggsproblem for fremmedspråklige leger er fornorskingen av det medisinske fagspråket. Her snakkes det om fugler: grå stær (cataract), grønn stær (glaucom), og dyr: røde hunder (rubella). Sykdommer har ofte norske navn: kyssesyke (mononucleose) og vannkopper (varicella). Inngrep fornorskes: utskrapning (abrasio, revisio). Anatomien er 
hyppig fornorsket: Hvor er trommehinnen (menbrana tympani), livmoren (uterus) og hovedpulsåren (aorta)?

Min påstand er at flere norske leger ville hatt problemer med å bestå B2-eksamen uten å ha fulgt kurset.

LITTERATUR:

1. Gedde TG. Lave språkkrav til leger fra utlandet. Tidsskr Nor Legeforen 2017; 137: 923 - 4. [PubMed]

2. Ellingsen E, Mac Donald K. Stein på stein. Oslo: Cappelen Damm, 2016.

3. Ellingsen E, Mac Donald K. Her på berget. Oslo: Cappelen Damm, 2016.

Publisert: 28. november 2017. Tidsskr Nor Legeforen. DOI: 10.4045/tidsskr.17.0953

(C) Tidsskrift for Den norske legeforening 2020. Lastet ned fra tidsskriftet.no 